\title{
A Tool for Monitoring Trichoderma harzianum: I. Transformation with the GUS Gene by Protoplast Technology
}

\author{
C. Thrane, M. Lübeck, H. Green, Y. Degefu, S. Allerup, U. Thrane, and D. Funck Jensen
}

First, second, third, fourth, and seventh authors: Plant Pathology Section, and fifth author: Plant Physiology and Anatomy Section, Institute of Plant Biology, The Royal Veterinary and Agricultural University, Thorvaldsensvej 40, DK-1871 Frederiksberg C, Denmark; and sixth author: Department of Biotechnology, Technical University of Denmark, DK- 2800 Lyngby, Denmark.

Current address of Y. Degefu: Plant Breeding Section, Department of Plant Biology, University of Helsinki, FIN-00710 Helsinki, Finland.

This work was supported by the Danish Agricultural and Veterinary Research Council (SJVF). Y. Degefu was supported by NorFa during his 2-month stay at the Plant Pathology Section.

We thank M. Krause Pedersen for technical assistance and J. Bresciani for useful information about hexamethyldisilzane (HMDS). We also thank P. Stephensen Lübeck for commenting on the manuscript.

Accepted for publication 28 August 1995.

\begin{abstract}
Thrane, C., Lübeck, M., Green, H., Degefu, Y., Allerup, S., Thrane, U., and Jensen, D. F. 1995. A tool for monitoring Trichoderma harzianum: I. Transformation with the GUS gene by protoplast technology. Phytopathology 85:1428-1435.

To obtain a genetically marked strain of Trichoderma harzianum that can be used as a tool for studies of population dynamics, T. harzianum was cotransformed with the Escherichia coli uid A $\beta$-glucuronidase (GUS) gene and the hygromycin B (hygB) gene as the selective marker. To improve the efficiency of conditions used for the transformation, the isolation, reversion, and germination of mycelial protoplasts were studied

ful for preparing protoplasts from suspensions for SEM. It was essential to obtain a transformant that phenotypically resembled the wild-type. After mitotic stabilization of the transformants by single-spore isolations, three transformants were compared to the wild-type by measurement of spore germination and mycelial growth rates, identification of secondary metabolite profiles, and studies of extracellular proteins. One transformant, T3c, was dissimilar to the wild-type in most tests, whereas transformant T3a was physiologically very similar to the wild-type. Furthermore, transformant T3a remained genetically stable during nonselective cultivation on plates and in sterile peat-bran.
\end{abstract} by scanning electron microscopy (SEM). Hexamethyldisilzane was use-
Additional keywords: reporter gene.
Trichoderma harzianum Rifai has received much attention because of its potential as a biocontrol agent of many plant pathogenic fungi (18). Recent results from field trials testing the biocontrol effect of $T$. harzianum indicate that isolates of this fungus work well under different environmental conditions, protecting several crops as well as controlling various plant pathogens (3). However, due to many environmental factors, most antagonistic microorganisms do not show consistent biocontrol effects. Therefore, it will be necessary to reduce the variability in the performance of fungal antagonists to make them attractive as alternatives to chemical pesticides. For this purpose, we need to know more about the ecology of the antagonists. Introduction of a genetically marked isolate of the antagonist in question into the environment allows us to differentiate this antagonist from indigenous isolates.

The selectable hygromycin (hygB) resistance gene is a useful marker for screening large samples of transformant and indigenous isolate mixtures with a minimum of effort, whereas the $\beta$ glucuronidase (GUS) gene, because it is a nondominant selectable marker, is useful only for a limited screening of soil samples. There are, however, several advantages in using GUS for studies of the ecology of T. harzianum. First, background GUS activity is rare in tested fungi and plants $(17,19)$. Second, the gene is constitutively expressed, which is valuable for evaluating the activity of the organism. Third, expression of the enzyme should not influence the biocontrol effect of the fungus. Fourth, the ability to stain the fungus in situ will provide knowledge about the spatial relationships of the antagonist in the soil and on the root. Fur-

Corresponding author: C. Thrane; E-mail address: dfj@kvl.dk

C다이 1995 The American Phytopathological Society thermore, there are several simple methods available for assaying GUS activity (17).

Plant pathogenic strains of Fusarium oxysporum (5) and Bipolaris sorokiniana (19) have been transformed with the GUS gene and used for studying root colonization. Transformants of Fulvia fulva (synamorph Cladosporium fulvum) and Leptosphaeria maculans (29), which also express GUS, have been used to detect and quantify the pathogens in infected plants. Transformation of fungi with the GUS gene or other markers can be accomplished using protoplasts $(12,14,26,30,31,39)$ or a biolistic technique recently developed for transformation of $T$. harzianum at high frequency by particle bombardment of conidia (21).

The first objective of this study was to cotransform $T$. harzianum with the hygB gene as the dominant selectable marker and the GUS reporter gene. The specific isolate was originally isolated from Pythium-suppressive peat (47) and consistently shows good biocontrol of Pythium spp. in growth-chamber studies with cucumber plants. To improve the efficiency of protoplast transformation, we used scanning electron microscopy (SEM) to study the physical events caused by the enzymatic preparation of protoplasts from fungal mycelia and the transformation and reversion of the protoplasts under the conditions used in this experiment. Critical point drying and a chemical method previously shown to stabilize fragile insect structures (24) were used to prepare the specimens for SEM.

The second objective of this study was to use physiological tests on selected transformants to choose a transformant that was phenotypically similar to the wild-type. These tests were designed to show whether single traits likely to be involved in the general metabolism of the fungus or, more specifically, in biocontrol were changed during the transformation. The growth rate, 
the ability to grow on different media, and the production of extracellular enzymes and secondary metabolites were examined. Prior to this, mitotically stable transformants were obtained from colonies arising after cultivation of single spores from putative heterocaryotic transformants.

\section{MATERIALS AND METHODS}

Strains and plasmids. T. harzianum isolate T3 was isolated from a $P$. ultimum Trow-suppressive sphagnum peat from Sweden (47). P. ultimum isolate HB2 was isolated from the field station at Højbakkegård, Denmark. The Escherichia coli strain MC1061 was used for propagation of plasmids (36). The plasmid pNOM102 containing the $E$. coli GUS gene (34) was donated by M. Penttilä, VTT, Helsinki, Finland. The plasmid pAN7-1 containing the $E$. coli hygB resistance gene and the derivative $\mathrm{pHAT} \alpha$ were donated by M. van Montagu (Lab. voor Genetica, Gent, Belgium). Both plasmids contained the constitutive Aspergillus nidulans gpd promoter. pHAT $\alpha$ was constructed by insertion of a $2.4-\mathrm{kb} \alpha$-amylase gene from T. harzianum into the HindIII site of pAN7-1 (14).

Media. Trichoderma minimal medium (TMM) (32) was used for cultivation of the fungus for DNA extraction and in the glucose-utilization experiment. Trichoderma selective medium (TSM) (6) was used as a selective medium for cultivation of Trichoderma for measurements of spore germination and growth rates. Potatodextrose agar (PDA) and potato-dextrose broth (PDB) (Difco Laboratories, Detroit) were used for fungal cultivation. A nutritionally poor medium, sphagnum extract agar (SEA), was prepared as follows: $200 \mathrm{~g}$ of sphagnum peat moss was soaked in distilled water for $24 \mathrm{~h}$ and was filtered through four layers of cheesecloth and then through filter paper. From this preparation, $400 \mathrm{ml}$ of sphagnum extract was mixed with $15 \mathrm{~g}$ of agar and $600 \mathrm{ml}$ of distilled water before autoclaving. Potato-sucrose agar (PSA) (2), rice meal agar (RM) (37), Sigma yeast extract sucrose agar (SYES; Sigma Chemical Company, St. Louis) (7), and yeast extract sucrose agar (YES) (37) were used for the production of secondary metabolites. To these four media, $1 \mathrm{ml}$ of trace elements per liter (41) was added, and YES and SYES were supplemented with 0.5 $\mathrm{g}$ of $\mathrm{MgSO}_{4}$ per liter. For the analysis of extracellular protein production, the following medium was used: $1 \mathrm{ml}$ of trace elements (32), $2 \mathrm{~g}$ of $\mathrm{NaNO}_{3}, 50 \mathrm{mM}$ 2-[ $\mathrm{N}$-morpholino]-ethanesulfonic acid buffer (pH 6.0), $2.3 \mathrm{~g}$ of $\mathrm{K}_{2} \mathrm{HPO}_{4}, 0.1 \mathrm{~g}$ of $\mathrm{KCl}, 2.4 \mathrm{ml}$ of 1 $\mathrm{M} \mathrm{MgSO}_{4}, 4.1 \mathrm{ml}$ of $1 \mathrm{M} \mathrm{CaCl}, 0.5 \mathrm{~g}$ of sucrose, $2 \mathrm{~g}$ of lactose (Sigma L-3750), $2 \mathrm{~g}$ of birke 150, $2 \mathrm{~g}$ of oat spelt xylan (Sigma $\mathrm{X}-0376$ ), and 1 liter of water. The birke 150 , which is substituted xylan from birch (acetylglucoronoxylan), was donated by M. Bailey, VTT, Helsinki, Finland.

Protoplast isolation. Conidia $\left(2 \times 10^{6}\right)$ were incubated in $100 \mathrm{ml}$ of PDB for $16 \mathrm{~h}$ at $28^{\circ} \mathrm{C}$ with shaking at $120 \mathrm{rpm}$. The mycelium was collected on four layers of cheesecloth and washed with 1.2 $\mathrm{M} \mathrm{MgSO}_{4}$. Mycelia (1 $\mathrm{g}$ fresh weight) was transferred to a petri dish containing $20 \mathrm{ml}$ of sterile filtered $(0.45-\mu \mathrm{m}$ filter) lysing enzyme (Sigma L-2265) solution (7.5 mg/ml in $1.2 \mathrm{M} \mathrm{MgSO}_{4}, 10$ $\mathrm{mM}$ sodium-phosphate buffer [pH 5.8]) and incubated for 2 to $4 \mathrm{~h}$ at $28^{\circ} \mathrm{C}$ with shaking at $50 \mathrm{rpm}$. Protoplasts were collected by filtering through six layers of cheesecloth, washed, and pelleted by centrifugation.

Preparation of specimens for SEM. For critical point drying (27), agar plugs from PDA plates with protoplasts were fixed for $3 \mathrm{~h}$ in $3 \%$ glutaraldehyde in $0.2 \mathrm{M}$ sodium-phosphate buffer $(\mathrm{pH}$ 6.8). Dehydration of the specimens was performed in acetone by incubation for $2 \mathrm{~h}$ in successively increasing acetone concentrations $(20,30,40,50,70,80$, and $100 \%)$. The specimens were dried in a Baltzer CPD 2000 (Baltzer, Kungsbacka, Sweden) using $\mathrm{CO}_{2}$. The preparation of specimens with hexamethyldisilzane (HMDS) was modified from Nation (24) as follows: protoplasts in STC (1.2 M sorbitol, $10 \mathrm{mM}$ TRIS- $\mathrm{HCl}, 50 \mathrm{mMCaCl}_{2}[\mathrm{pH}$ $7.5]$ ) suspension were pelleted by centrifugation ( $5 \mathrm{~min}$ at $400 \times \mathrm{g}$ ).
Fixation was done in glutaraldehyde as described above. Dehydration was performed in successively increasing ethanol concentrations $(50,60,70,80$, and $96 \%$ ) for $15 \mathrm{~min}$. HMDS (50 $\mu \mathrm{l}$; Sigma H-4875) was added to the final pellet. Forty microliters of suspension was placed on a glass plate and dried under a glass lid for $5 \mathrm{~min}$. The specimens were mounted on stubs, given a gold coat of $200 \AA$ in a Polaron high resolution sputter coater (BioRad, Polaron Division, Watford, England) and viewed in a scanning electron microscope (JEOL JSM 840A; Jeol Ltd., Tokyo).

Protoplast regeneration frequency. The frequency of nontransformed protoplasts was determined by the most probable number method (11). Colonies developed on plates incubated for 2 to 7 days at $25^{\circ} \mathrm{C}$. A regeneration medium was used that included $10 \%$ (wt/vol) sucrose as an osmotic stabilizer (43). This was carried out twice.

Transformation of protoplasts. Plasmid DNA $(5 \mu \mathrm{g}$ each of pNOM102 and pHAT $\alpha$ ) in $20 \mu \mathrm{l}$ of Tris-EDTA buffer (36) was used to transform $200 \mu \mathrm{l}$ of protoplasts $\left(10^{6}\right.$ to $\left.10^{7} / \mathrm{ml}\right)$. The transformation was essentially carried out as described by Penttilä et al. (32), except the protoplasts were preincubated on PDA containing $1.0 \mathrm{M}$ sorbitol for $16 \mathrm{~h}$ before overlaying the agar with selective agar (PDA, 1.0 M sorbitol, and $100 \mu \mathrm{g}$ of hygromycin B per ml [Sigma H-8272]) Putative transformants were chosen after incubation at $28^{\circ} \mathrm{C}$ for 5 to 7 days and several transfers to selective media. Colonies growing on the hygromycin B-selective media were tested for GUS activity to confirm cotransformation. For each isolate, three single-conidial isolations were carried out to eliminate isolates containing heterokaryons, thus selecting isolates recovered from cotransformed nuclei; after this, the transformants were mitotically stable. As a test for genetic stability, T3a was cultivated under nonselective conditions for 2 months before 200 colonies from the inoculum were tested for hygromycin B resistance and GUS activity. To determine the number of nuclei, conidia were stained with fluorescent 4'-6-diamidino-2phenylindole according to Sivan et al. (38) and viewed under a Nikon Optihot epifluorescence microscope (Nikon, Tokyo).

Standard DNA procedures. Plasmid propagation and handling were performed according to Sambrook et al. (36). Fungal DNA was isolated according to the procedures of Raeder and Broda (33). The nonradioactive PolarPlex kit from Millipore (Bedford, MA) was used for Southern blot hybridization, according to the manufacturer's instructions, with a hybridization temperature of $68^{\circ} \mathrm{C}$. A $2-\mu \mathrm{g}$ probe was labeled and hybridized to the filter. Fungal DNA $(20 \mu \mathrm{g})$ and plasmid DNA $(20 \mathrm{ng})$ were loaded on the gel. The probe used for the GUS gene was the Sall-SalI fragment of the pNOM102 plasmid, and for the hygB gene, the HindIIIEcoRI fragment from pAN7-1 was used.

GUS assays. Three methods were used to assay for GUS activity. Method I: The transformants were tested for GUS activity in a microtiter plate by incubating fresh mycelium in $200 \mu \mathrm{l}$ of sodium-phosphate buffer ( $\mathrm{pH}$ 7.0) supplemented with $4 \mu \mathrm{l}$ of substrate (4 mg of 5-bromo-4-chloro-3-chloro $\beta$-D-glucuronide [Sigma B-0522] in $1 \mathrm{ml}$ of $50 \mathrm{mM}$ sodium-phosphate buffer, $\mathrm{pH}$ 7.0) in the dark for $1 \mathrm{~h}$ at room temperature. Method II: Nonsporulating transformants were tested for GUS activity on plates by wounding the mycelium, adding $4 \mu \mathrm{l}$ of substrate (as above), and incubating in the dark for $1 \mathrm{~h}$ at room temperature. Method III: $10^{7}$ conidia were added to $50 \mathrm{ml}$ of TMM and incubated at $25^{\circ} \mathrm{C}$ as shake cultures ( $\left.150 \mathrm{rpm}\right)$ for $72 \mathrm{~h}$ to determine activity of mycelial extracts. Extraction of the enzyme from the mycelia was carried out according to the methods of van Gorcom et al. (46). The activity was measured as described for $\beta$-galactosidase (34) using $200 \mu \mathrm{l}$ of enzyme extract and $p$-nitrophenyl $\beta$-D-glucuronide (Sigma N-1627) as the synthetic substrate for GUS. From each enzyme reaction, the absorbance was measured at $405 \mathrm{~nm}$ in triplicates. The $A_{280 \mathrm{~nm}}$ of the enzyme extracts was measured to estimate the protein content. Likewise, GUS was extracted from 2-month-old peat-bran inoculum of T3a; extraction and activity assays were performed as described by Green and Jensen (13). 
Physiological tests. In one dual-culture experiment, the in vitro interaction between the wild-type $T$. harzianum inoculated opposite to the individual transformants was compared. In another dual-culture experiment, the wild-type and the transformants T3a, $\mathrm{T} 3 \mathrm{~b}$, and T3c were inoculated opposite the plant pathogen $P$. ultimum. In both experiments, PDA was used as the substrate, and the plates were incubated at $25^{\circ} \mathrm{C}$. To measure the growth rates on

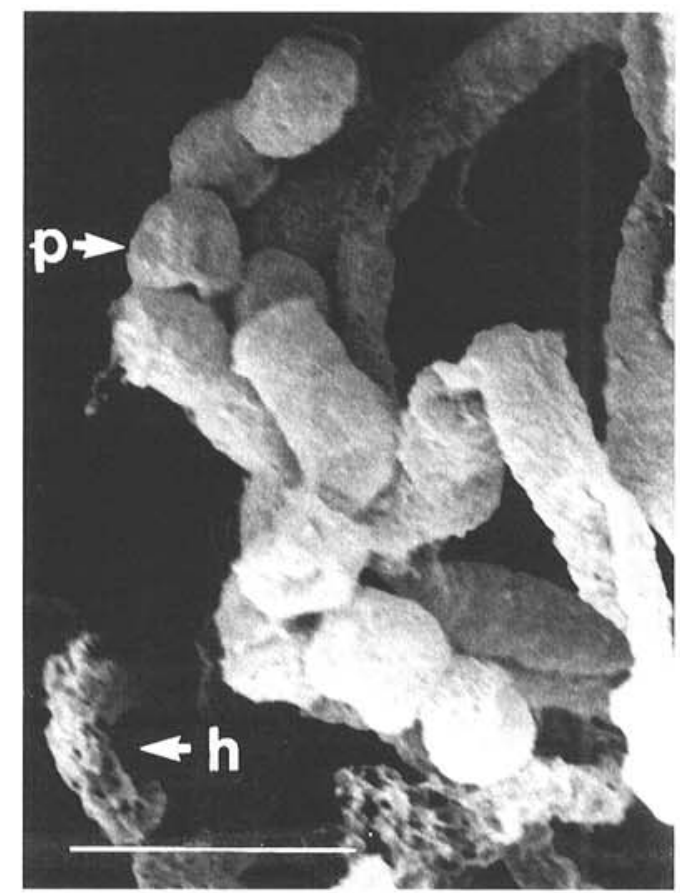

Fig. 1. Scanning electron micrograph of release of protoplasts of Trichoderma harzianum from mycelia. Hyphae are thin and porous due to the enzymatic breakdown of cell walls. Some of the hyphae are broken. The protoplasts were closely associated after 90-min of incubation in lysing enzymes. $\mathrm{Bar}=10 \mu \mathrm{m} . \mathrm{p}=$ protoplast. $\mathrm{h}=$ hyphal remnant. Critical point drying method was used.

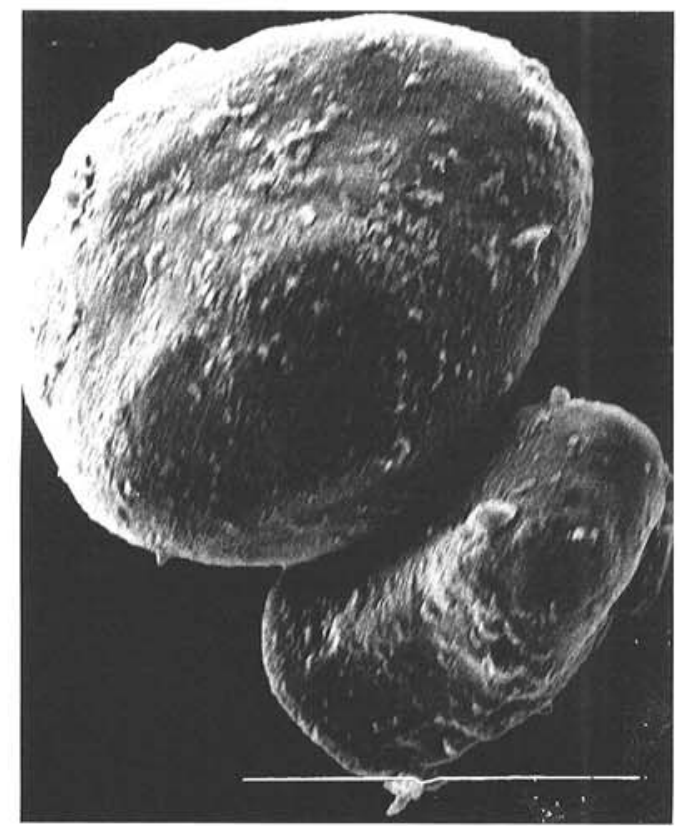

Fig. 2. Scanning electron micrograph (SEM) of two closely associated Trichoderma harzianum protoplasts. The protoplasts were stored at $4{ }^{\circ} \mathrm{C}$ and then fixed for SEM $4 \mathrm{~h}$ after release from mycelia. No fibrils can be seen on the membranes. Bar $=10 \mu \mathrm{m}$. Hexamethyldisilzane method was used. solid media (PDA and SEA) in petri dishes, agar plugs of the wild-type and the transformants were used as inoculum. The cultures were incubated at $25^{\circ} \mathrm{C}$. The average diameter of the colonies of three replicates was measured at time intervals. Growth under selective pressure was tested on PDA plates supplemented with $0,50,100$, and $200 \mu \mathrm{g}$ of hygromycin B per ml and on TSM plates supplemented with 0,50 , and $100 \mu \mathrm{g}$ of hygromycin B per $\mathrm{ml}$ by inoculation with agar plugs. The average diameter of the colonies was measured at time intervals (for up to $190 \mathrm{~h}$ ) for three replicates. Germination of conidia was tested by dilution plating of approximately 25 conidia from each isolate on PDA amended with $0.25 \%$ Triton X-100 and TSM. Three replicates from three individual conidial suspensions were plated. The plates were incubated for 4 days at $25^{\circ} \mathrm{C}$ before the developed colonies were counted. Glucose utilization in liquid culture was analyzed with a kit from Boehringer GmbH (Mannheim, Germany) (test combination glucose GOD-Perid 124028). The shake cultures $\left(10^{7} \mathrm{co}-\right.$ nidia per flask) were incubated in $100 \mathrm{ml}$ of TMM at $25^{\circ} \mathrm{C}(150$ $\mathrm{rpm})$. Samples were taken daily for determination of glucose utilization and $\mathrm{pH}$.

For the analysis of secondary metabolite profiles by high performance liquid chromatography with diode array detection (HPLCDAD), the wild-type and the transformants were cultured in the dark for 14 days at $25^{\circ} \mathrm{C}$ on PSA, RM, SYES, and YES. Three replicates from each isolate were cultured, extracted, and subjected to HPLC-DAD analysis (9) modified according to Thrane (42).

Extracellular proteins produced during cultivation in a complex carbon medium were collected from three 10 -ml shake cultures (50-ml flasks) of each isolate $\left(5 \times 10^{4}\right.$ conidia per $\left.\mathrm{ml}\right)$ that had been incubated for 4 days at $25^{\circ} \mathrm{C}$. The cultures were filtered $(0.2$ $\mu \mathrm{m})$, and the filtrates were used as the crude protein extract. Total protein was determined with the Bio-Rad protein assay kit II. The protease assay was done with $0.2 \%$ Hide azure (Sigma H-6268) in $50 \mathrm{mM}$ sodium-phosphate buffer (pH 5.6). Culture filtrate (400 $\mu \mathrm{l})$ was incubated with $400 \mu \mathrm{l}$ of Hide azure solution for $1 \mathrm{~h}$ and shaken vigorously at $37^{\circ} \mathrm{C}$. The reaction was stopped by the addition of $250 \mu \mathrm{l}$ of $50 \%$ trichloroacetic acid followed by incubation for $30 \mathrm{~min}$ at $-20^{\circ} \mathrm{C}$ and centrifugation $(12000 \times \mathrm{g})$ for 10 min to pellet excess Hide azure. Absorbance of the supernatant was measured at $595 \mathrm{~nm}$.

Cellulase azure (Sigma C-1052) was used as the substrate for cellulases. The assay was similar to the Hide azure assay, except $0.5 \%$ substrate was used, and centrifugation to pellet excess substrate was done immediately after the reaction was stopped with $700 \mu \mathrm{l}$ of cold $96 \%$ ethanol. To assay the activity of cellobiohydrolase, $\beta$-galactosidase, and $\beta$-glucosidase, the synthetic $p$ nitrophenyl substrates (Sigma N-5759, N-1252, and N-7006) were used. The assay was carried out as described above for the GUS enzyme (method III). For isoelectric focusing (IEF), the culture filtrates were pooled and subsequently desalted and concentrated twofold by centrifugation in Centriprep-3000 according to the manufacturers' directions (Amicon, Beverly, MA). To the concentrated culture filtrates, Tris- $\mathrm{HCl}(\mathrm{pH} 7.0)$ and glycerol were added to give final concentrations of $10 \mathrm{mM}$ and $4 \%$ respectively. The Phastsystem (Pharmacia LKB, Uppsala, Sweden) was used for IEF (Phast IEF gel [3-9]). Activity assay of the IEF gels was done for endochitinase and cellulase according to Tronsmo and Harman (45) and Penttilä et al. (31), respectively. An activity gel using 4-methylumbelliferyl- $\beta$-D-xyloside (Sigma M-7008) also was carried out according to Tronsmo and Harman (45).

Statistical analysis. SAS PROC GLM (SAS Institute, Cary, NC) was used for the statistical analysis. The Duncan test was used to distinguish between statistically significant results. For the analysis of the secondary metabolite profiles, the peak areas from the HPLC-DAD chromatograms were $\log _{10}$-transformed before being subjected to correspondence analysis (8) using NTSYS-pc version 1.80 (Exeter Biological Software, Setauket, NY) (35). The 
dual-culture experiments, the GUS assay of mycelial extracts, the glucose-utilization experiment, and the protease and cellulase enzyme assays were repeated twice.

\section{RESULTS}

Protoplast isolation and regeneration. Microscopy showed that the isolated mycelial protoplasts ranged in size from 4 to 15 $\mu \mathrm{m}$. After 2 to 7 days, 10 to $30 \%$ of the protoplasts were able to form colonies. The optimal incubation time in lysing enzymes was 3 to $4 \mathrm{~h}$. Incubating for a shorter period revealed large aggregates of protoplasts that were inconvenient for transformation, whereas too long an exposure time to the enzyme could be harmful to the protoplasts. After 3 to $4 \mathrm{~h}$ of incubation, only a few protoplasts were associated after the release from the cell walls (Figs. 1 and 2). The wall structure of the germinated protoplast (Fig. 3) collapsed, probably due to a lack of mechanical support in the cell wall. The developed hyphae were irregularly shaped. By comparison with SEM of older mycelia (data not shown), it appeared that the germ tube (Fig. 3) had not yet developed a septum.

The structures shown in Figures 2 and 4 were prepared for SEM by the HMDS method, which preserved the shapes of the protoplasts from isotonic solutions and made it possible to see the developing cell wall structures. On the protoplasts placed at $4{ }^{\circ} \mathrm{C}$ immediately after release, no apparent cell wall development could be seen (Fig. 2). After incubation for only $1 \mathrm{~h}$ at room temperature, the deposition of cell wall material had already begun (Fig. 4).

Stabilization and verification of transformants. Before transformation, the wild-type $T$. harzianum isolate T3 was tested for its indigenous hygromycin B tolerance. Initially, PDA supplemented with hygromycin B was used for this purpose. Selection on this medium was not reliable because the activity of the antibiotic apparently was reduced in this medium. Wild-type T. harzianum was able to grow on $50 \mu \mathrm{g} / \mathrm{ml}$, and an isolate of $T$. virens (Gliocladium virens) grew on $300 \mu \mathrm{g}$ of hygromycin B per $\mathrm{ml}$ in PDA plates, whereas no background growth was present with any of the isolates in the defined medium (TSM) supplemented with $50 \mu \mathrm{g}$ of hygromycin B per $\mathrm{ml}$.

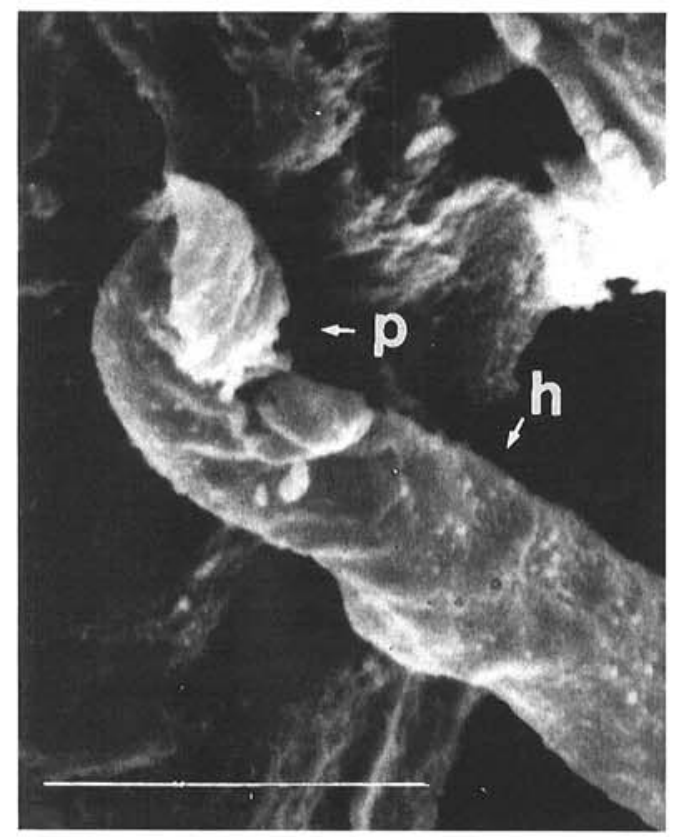

Fig. 3. Scanning electron micrograph of Trichoderma harzianum hypha developed from a protoplast. No septae seemed to have formed by comparison of this newly regenerated mycelium to older mycelium (picture not shown). The protoplast is probably collapsed. The protoplast was incubated at $25^{\circ} \mathrm{C}$ for $48 \mathrm{~h}$ on potato-dextrose agar. $\mathrm{p}=$ collapsed protoplast. $\mathrm{h}=$ irregular shaped hypha. $\mathrm{Bar}=10 \mu \mathrm{m}$. Critical point drying method was used.
The frequency of transformation to hygromycin B tolerance was about 30 transformants/ $\mu$ g of DNA. Ten transformants were checked for cotransformation with the GUS gene, of which five were positive. Three of these initial transformants (T3a, T3b, and T3c) were chosen for further studies because their colony appearance was similar to the wild-type. By staining nuclei, the conidia were identified as uninucleate (data not shown). This fact verified the rational of making single-conidium isolations to achieve mitotically stable transformants. Each isolate arose from one cotransformed nucleus.

For the transformant T3a, mitotic stability with respect to both genes was confirmed after cultivation for 8 months without hygromycin B selection pressure on plates and in peat-bran. No reversion to the wild-type phenotype was detected. There were no background signals of the wild-type genomic DNA at the high stringency used for the Southern hybridization (Figs. 5 and 6). The blots verified that the genes encoding GUS and hygB resistance had been integrated into the genome. Only high molecular weight signals were seen when hybridizing to the undigested

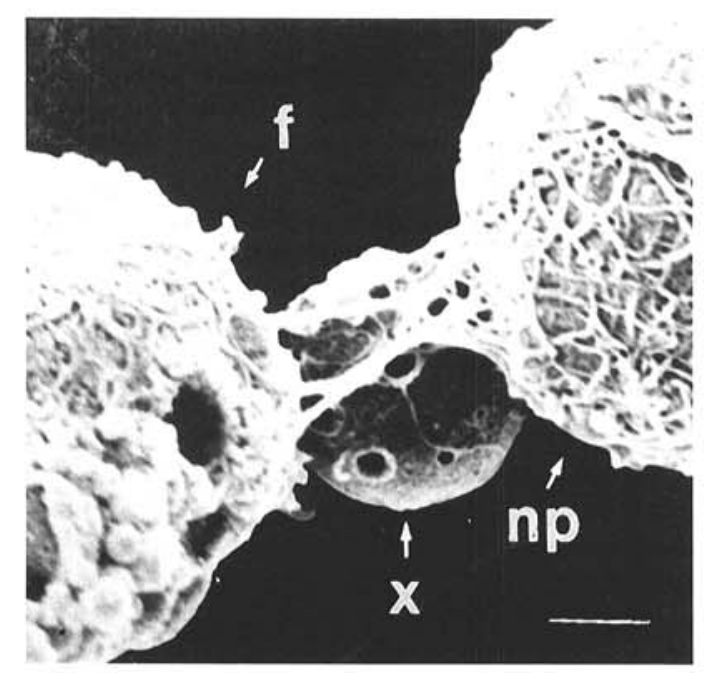

Fig. 4. Scanning electron micrograph of Trichoderma harzianum fibrils growing on protoplasts and from one protoplast to the other. Protoplasts were incubated $1 \mathrm{~h}$ at room temperature and then kept at $4^{\circ} \mathrm{C}$ for $3 \mathrm{~h}$. One of the protoplasts may not be able to regenerate because of holes in the wall. The structure $(\mathrm{x})$ is probably a vesicle, a nucleus, or a small protoplast. $\mathrm{np}=$ nonregenerating protoplast. $\mathrm{f}=$ fibrils on regenerating protoplast. $\mathrm{x}=$ putative nucleus. $B a r=1 \mu \mathrm{m}$. Hexamethyldisilzane method was used.

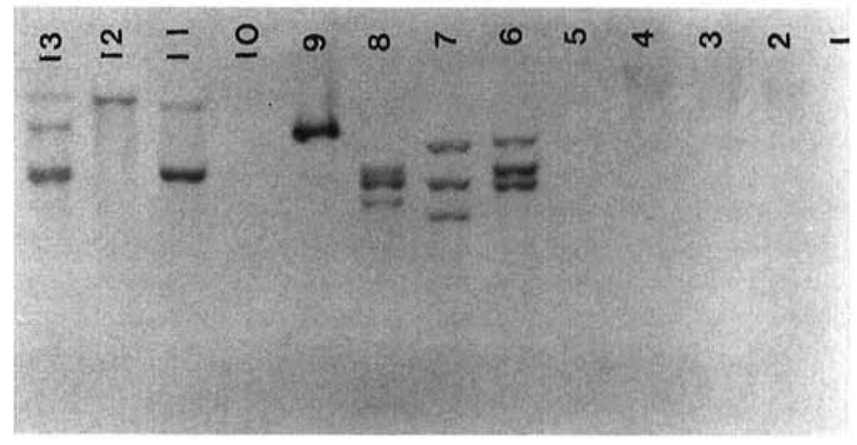

Fig. 5. Southern blot analysis of genomic DNA from the Trichoderma harzianum wild-type isolate and the transformants probed with the HindIII-EcoRI fragment from pAN7-1 including the hygromycin B gene. Lanes 1, 5, and 10: wild-type. Lanes 2, 6, and 11: transformant T3a. Lanes 3, 7, and 12: transformant T3b. Lanes 4, 8, and 13: transformant T3c. Lane 9: pHAT $\alpha$ digested with BamHI. Lanes 1-4: undigested DNA. Lanes 5-9: BamHI-digested DNA (pHAT $\alpha$ had one restriction site for BamHI). Lanes 10-13: EcoRV-digested DNA (pHAT $\alpha$ had no restriction site for EcoRV). 
genomic DNA of the transformants with the two probes (this result was only shown for the hygB gene). The patterns of integration were complex and appeared to differ for the three transformants. Judged by the size of the hybridization signals, the smaller bands might represent deletions of the plasmid.

The wild-type isolate did not grow on $50 \mu \mathrm{g}$ of hygromycin B per $\mathrm{ml}$, whereas the transformants grew very well on at least 100

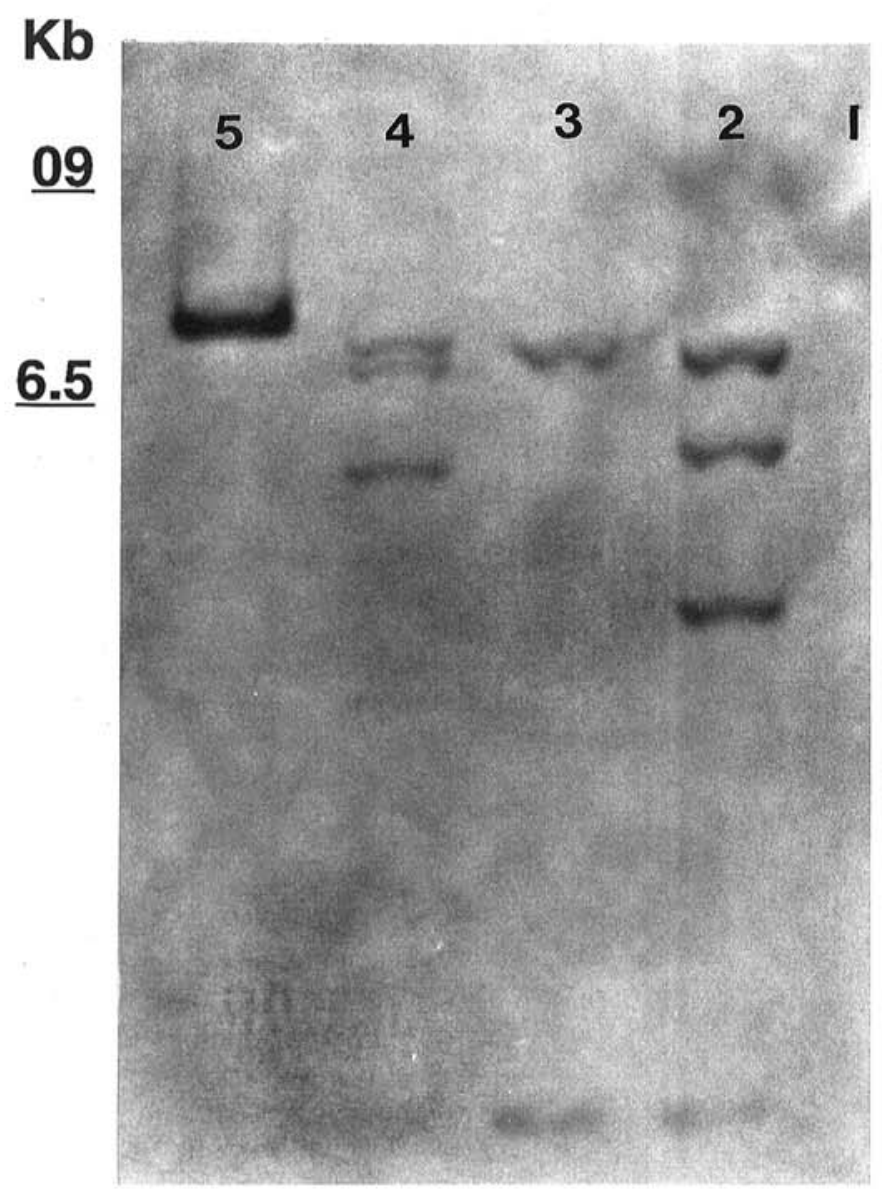

Fig. 6. Southern blot analysis of genomic DNA from the Trichoderma harzianum wild-type isolate and the transformants probed with the SalI-SalI fragment of pNOM102 including the $\beta$-glucuronidase gene. Lane 1: wild-type. Lane 2: transformant T3a. Lane 3: transformant T3b. Lane 4: transformant T3c. Lane 5: pNOM102. The DNA was digested with EcoRI (pNOM102 had one restriction site for EcoRI).

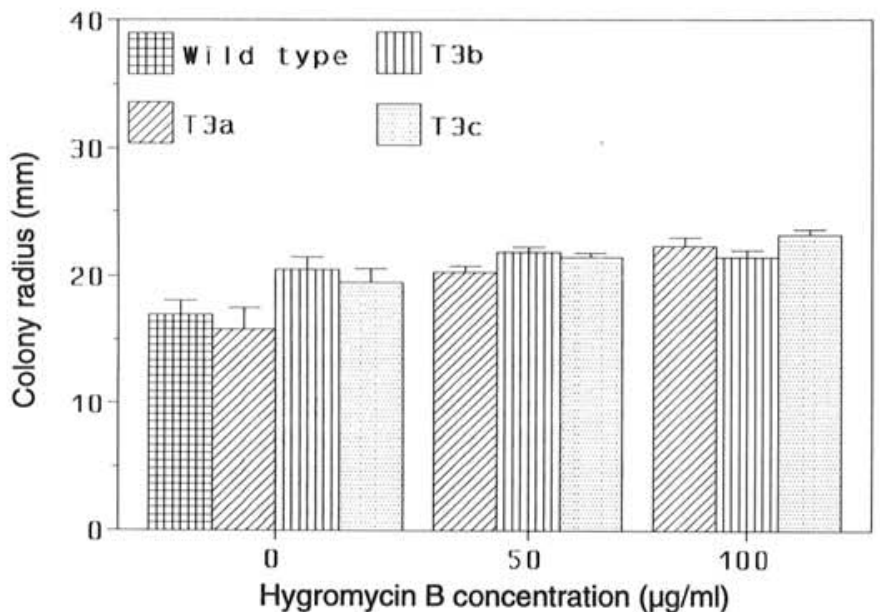

Fig. 7. Growth on Trichoderma selective-medium plates supplemented with 0,50 , and $100 \mu \mathrm{g}$ of hygromycin B per $\mathrm{ml}$. The diameter of the colonies was measured at time intervals. There were three replicates of each isolate. The vertical bars represent the standard error. $\mu \mathrm{g}$ of hygromycin B per ml (Fig. 7). GUS activity could not be detected in mycelial enzyme extracts of the wild-type isolate (method III) nor in plate assays (method II). There was no significant difference between the GUS-activity measurements (GUS activity per total amount of extractable protein) of mycelial extracts among the transformants. This was not surprising because these transformants were picked in the initial GUS assay for high activity (method I). Very low but detectable activity of the GUS enzyme could be measured in extracts of resting conidia of the transformants cultivated in peat-bran.

Physiological tests of transformants. In dual cultures of $T$. harzianum in which the transformants were paired with the wildtype isolate, identical growth patterns were seen, except in the case of T3c, which overgrew the wild-type (data not shown). In the dual-culture experiment with each of the transformants and $P$. ultimum (data not shown), macroscopically the growth of T3c and the pathogen also appeared different from the other isolates. Furthermore, on plates, sporulation of T3c was sparse and delayed compared to the other isolates.

The growth rates on rich (PDA) and poor (SEA) media were compared. On PDA, there were significant statistical $(P<0.015)$ differences in growth among the isolates after $51 \mathrm{~h}$ of incubation; T3c was the slowest growing (Table 1). On SEA, there was no significant statistical difference $(P>0.05)$ among the isolates. The ability to germinate on TSM or PDA was compared and did not show any significant differences among the isolates (data not shown). Glucose utilization of shake cultures revealed no significant differences among the isolates, but after $42 \mathrm{~h}$ of incubation, the $\mathrm{pH}$ of $\mathrm{T} 3 \mathrm{c}$ culture filtrate was statistically significantly lower $(P<0.02)$ than the $\mathrm{pH}$ of other isolates (data not shown). In general, there was only a slight difference in growth rate on TSM among the four isolates (Fig. 7). T3b and T3c grew significantly faster $(P=0.02)$ than did the wild-type and T3a isolates at $90 \mathrm{~h}$ of incubation. On selective medium with 50 and $100 \mu \mathrm{g}$ of hygromycin B per $\mathrm{ml}$, there were no significant differences in growth ability among the transformants (Fig. 7), as a result $50 \mu \mathrm{g}$ of hygromycin B per ml was used as the concentration of the antibiotic for selection of transformants.

From the HPLC-DAD analysis, 21 secondary metabolites present in all extracts were characterized by their UV spectrum and retention time index (9). However, none of the separated metabolites could be identified further. The correspondence analysis of the $\log _{10}$-transformed data on peak areas separated the objects (i.e., the extracts) into three groups (Fig. 8) based on $86 \%$ of the variance of the chemical data. The three axes in Figure 8 represent factors 1 through 3 , which explain 36,33 , and $17 \%$, respectively, of the variance in the data set. The replicates of transformants T3b (T3b1, T3b2, and T3b3) and T3c (T3c1, T3c2, and $\mathrm{T} 3 \mathrm{c} 3$ ) clustered in two separate groups, whereas the replicates of transformant T3a (T3a1, T3a2, and T3a3) and wild-type T3 (T31, T3-2, and T3-3) clustered together. It was impossible to distinguish between the wild-type and transformant T3a based on quantitative chemical data. The T3c cluster and T3/T3a cluster were far from each other, indicating that transformant T3c was dissimilar to the wild-type. T3b also was separated from the wild-type, although it was somewhat closer to the wild-type than was T3c.

TABLE 1. Growth of the Trichoderma harzianum wild-type isolate and the transformants $\mathrm{T} 3 \mathrm{a}, \mathrm{T} 3 \mathrm{~b}$, and $\mathrm{T} 3 \mathrm{c}$ on potato-dextrose agar ${ }^{\mathrm{z}}$

\begin{tabular}{lcccc}
\hline \multirow{2}{*}{ Isolate/ } & \multicolumn{4}{c}{ Time of incubation } \\
\cline { 2 - 5 } Transformant & $17 \mathrm{~h}$ & $25 \mathrm{~h}$ & $43 \mathrm{~h}$ & \multicolumn{1}{c}{$51 \mathrm{~h}$} \\
\hline Wild-type & $8.2 \mathrm{~A}$ & $15.3 \mathrm{~B}$ & $40.8 \mathrm{~B}$ & $52.2 \mathrm{~B}$ \\
T3a & $9.8 \mathrm{~A}$ & $17.8 \mathrm{~A}$ & $43.0 \mathrm{~A}$ & $55.0 \mathrm{~A}$ \\
T3b & $8.2 \mathrm{~A}$ & $16.2 \mathrm{AB}$ & $41.8 \mathrm{AB}$ & $52.8 \mathrm{AB}$ \\
T3c & $6.2 \mathrm{~B}$ & $11.7 \mathrm{C}$ & $34.8 \mathrm{C}$ & $46.5 \mathrm{C}$ \\
\hline
\end{tabular}

$\mathrm{z}$ Values represent the average colony diameter. Values followed by different letters are statistically significantly different $(P<0.015)$. 
Protein analysis of the culture filtrates after growing the isolates on complex carbohydrates showed some differences between the isolates (Table 2). The total amount of extracellular protein was significantly lower $(P<0.038)$ in the culture filtrate from $\mathrm{T} 3 \mathrm{c}$ than from the other isolates. The specific cellulase activity was significantly higher $(P<0.015)$ in T3c. The average protease activity was not significant in the first experiment, but in the repeated experiment, significantly lower $(P<0.0015)$ protease activity was found in T3c compared to the other isolates. Only minor differences were seen in the specific activities of cellobiohydrolase and $\beta$-glucosidase, whereas T3c produced significantly higher specific $\beta$-galactosidase activity. Silver-stained IEF gels of the concentrated extracellular proteins apparently showed the same band pattern for the four isolates, although some differences could be seen (data not shown). The activity assays on the IEF gels for detection of endochitinase and xylosidase activity revealed one major band for each of the substrates (data not shown). For cellulase activity, four major bands could be detected. The intensities and pIs of bands detected on the activity gels were the same for all the isolates (data not shown).

\section{DISCUSSION}

T. harzianum was transformed stably with the GUS gene from E. coli in cotransformation with the hyg B gene as a selection marker, as revealed by Southern blot hybridizations (Figs. 5 and 6). Transformants $\mathrm{T} 3 \mathrm{a}, \mathrm{T} 3 \mathrm{~b}$, and $\mathrm{T} 3 \mathrm{c}$ were mitotically stable with respect to both genes after three successive single-conidium isolations, and the selected transformant T3a was stable for 8 months during subcultivations on nonselective plates and in peat-bran. Transformant T3c, although morphologically similar, differed physiologically from the wild-type isolate in many aspects.

Transformation with the polyethylene glycol (PEG) method depends on wall-less cells, so we studied how quickly the proto-

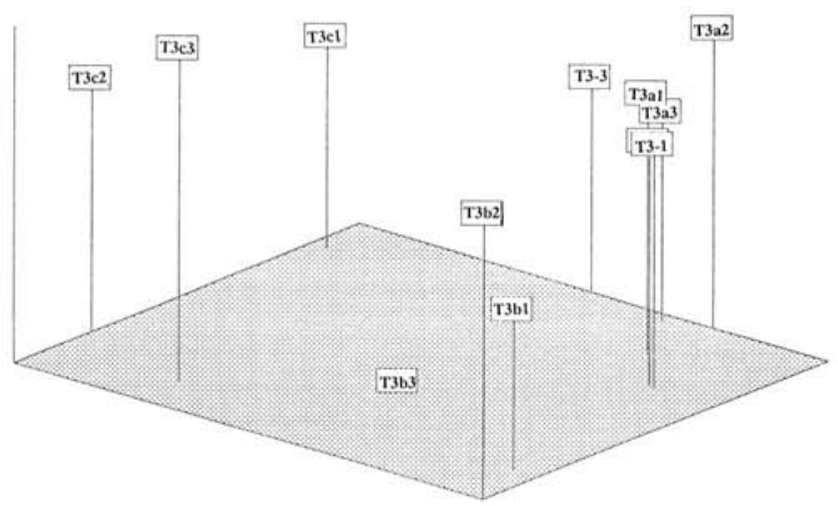

Fig. 8. Correspondence analysis of the secondary metabolite data. The Trichoderma harzianum isolates are labeled $\mathrm{T} 3, \mathrm{~T} 3 \mathrm{a}, \mathrm{T} 3 \mathrm{~b}$, and $\mathrm{T} 3 \mathrm{c}$ for the wildtype isolate and the transformants, respectively, followed by a number for the three replicates of each of the four isolates. The three axes represent the first three components (factors 1 through 3 ), which explain 36, 33, and $17 \%$ of the variance in the data set, respectively. plasts reverted to cells with walls. The deposition of cell wall polymers on the protoplast membrane was seen already $1 \mathrm{~h}$ after release from mycelia (Fig. 4). The size difference of a whole population of mycelial protoplasts (Fig. 2) is likely to reflect the cell content, which has an impact on regeneration capacity (15, $16,28,43$ ). For example, Sivan et al. (38) found that the number of nuclei in mycelial protoplasts of $T$. harzianum ranged from 0 to 10. Therefore, the regeneration capacity of a whole population of mycelial protoplasts is in general low, but physiologically more homogenous protoplasts can be obtained by interphase separation after incubation in lysing enzymes (32). The osmoinstability of reverting and germinating protoplasts as well as the irregularity of developing hyphae (Fig. 3) have been reported for other species $(23,25)$. Protection of the protoplasts from osmotic shock on plates, therefore, seems to be one of the parameters that should be optimized to increase the yield of transformants, because many of the protoplasts studied by SEM were lysed (e.g., as the structure seen in Figure 4). Another step that is likely to be even more critical for protoplasts is the PEG treatment for induction of transformation. PEG induces irreversible physiological changes in the membrane (48). This may be the reason why many fewer transformants were obtained by PEG treatment than by electroporation (14).

Mycelial protoplasts contain up to 10 nuclei (38), of which only one or a few might be transformed. Sivan et al. (39) documented that growth of transformed mycelia on hygromycin B requires only a very low percentage of transformed nuclei within a mycelium growing under hygromycin B selection pressure. For the purpose of our studies, we need to have a tag on the fungus that enables us to identify the introduced GUS/hygB transformant quantitatively. Loss or dilution of the introduced genes under nonselective conditions would spoil the opportunity to make quantitative and reproducible experiments. Stabilization of the transformants by single-conidium isolation was essential to eliminate nontransformed heterokaryons. Direct introduction of the DNA into conidia (21) could be advantageous because stabilization of the transformants would be more straightforward.

The purpose of transforming $T$. harzianum with marker genes was to obtain a tool for ecological studies of this antagonist (13). Together with the hygB gene, the suitability of the AmdS gene from $A$. nidulans for large-scale reisolation from ecological experiments also was tested in our laboratory (M. Lübeck, Y. Degefu, and D. F. Jensen, unpublished data). The AmdS gene previously has been useful as a dominant selectable marker to transform T. harzianum for the same purpose (30). However, our wildtype $T$. harzianum isolate grew just as well as the transformants on the AmdS-selective medium containing either acetamide or acrylamide as the nitrogen source. Sivan et al. (39) reported similar observations. Considering the GUS gene as a useful marker, there was no problem with background GUS activity in T. harzianum or in other fungi and plants that had been transformed with the GUS gene $(5,17,19,29,34)$, but in unsterile systems or in natural soils, background GUS activity might be present. This is in contrast to A. niger, which has an indigenous acidic GUS activity (T. E. Gottschalk, personal communication). The T3 iso-

TABLE 2. Analysis of culture filtrates from the Trichoderma harzianum wild-type isolate and the transformants T3a, T3b, and T3c grown in a complexcarbon medium ${ }^{y}$

\begin{tabular}{|c|c|c|c|c|c|c|}
\hline Isolate/Transformant & $\begin{array}{l}\text { Protein } \\
(\mu \mathrm{g} / \mathrm{ml})\end{array}$ & $\begin{array}{c}\text { Protease } \\
(\mathrm{A} / \mu \mathrm{g} \text { protein })^{\mathrm{z}}\end{array}$ & $\begin{array}{c}\text { Cellulase } \\
(\mathrm{A} / \mu \mathrm{g} \text { protein }) \\
\end{array}$ & $\begin{array}{c}\text { Cellobiohydrolase } \\
(\mathrm{A} / \mu \mathrm{g} \text { protein })\end{array}$ & 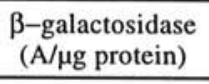 & $\begin{array}{l}\beta \text {-glucosidase } \\
(\mathrm{A} / \mu \mathrm{g} \text { protein) }\end{array}$ \\
\hline Wild-type & $143 \mathrm{~A}$ & $26 \mathrm{~A}$ & $22 \mathrm{~B}$ & $136 \mathrm{~A}$ & $40 \mathrm{~B}$ & $138 \mathrm{~A}$ \\
\hline $\mathrm{T} 3 \mathrm{a}$ & $140 \mathrm{~A}$ & $23 \mathrm{~A}$ & $22 \mathrm{~B}$ & $100 \mathrm{~A}$ & $43 \mathrm{~B}$ & $103 \mathrm{~A}$ \\
\hline T3b & $152 \mathrm{~A}$ & $31 \mathrm{~A}$ & $21 \mathrm{~B}$ & $111 \mathrm{~A}$ & $45 \mathrm{~B}$ & $123 \mathrm{~A}$ \\
\hline $\mathrm{T} 3 \mathrm{c}$ & $108 \mathrm{~B}$ & $5 \mathrm{~A}$ & $28 \mathrm{~A}$ & $110 \mathrm{~A}$ & $70 \mathrm{~A}$ & $134 \mathrm{~A}$ \\
\hline
\end{tabular}

${ }^{y}$ Three replicates of each isolate were analyzed, except T3c (two replicates). Results are from the first repeat trial. Values followed by different letters are statistically significantly different (protein: $P<0.038$; cellulase: $P<0.015$; and $\beta$-galactosidase: $P<0.0015$ ).

${ }^{z}$ Activity $(\mathrm{A})$ is defined as absorbance per $\mathrm{ml}$ of culture filtrate. 
late has an indigenous acidic $\beta$-galactosidase enzyme, so transformation with this gene is less attractive (12).

To use a GUS transformant in ecological studies, it is crucial that the selected genetically marked strain is phenotypically similar to the wild-type. Fungal antagonism is believed to be complex and dependent on many factors, such as niche and nutrient competition as well as production of secondary metabolites (4) and lytic enzymes $(1,10,20,22,44)$. To physiologically compare the isolates, simple tests were designed to evaluate whether changes related to antagonistic factors had occurred during the transformation. Although performed under artificial conditions, the measurements of growth rate, sporulation capacity, ability to colonize rich and poor substrates, and germination capacity gave useful information about the ability of the fungus to grow and reproduce, which are basic requirements for biocontrol.

The isolates were cultivated in a medium rich in complex carbohydrates because $T$. harzianum is capable of producing a range of plant cell wall- and fungal cell wall-degrading enzymes that are very likely to be involved in the ability of the fungus to control plant diseases (22). Enzyme activities and pI values of a few expected relevant hydrolytic enzymes ( $\beta$-galactosidase, protease, chitinase, endo- and exocellulases, and xylosidase) were measured in the culture filtrates. Furthermore, the transformants were subjected to HPLC analysis of their secondary metabolites because many secondary metabolites likely to play a role in antibiosis of the pathogens are produced by T. harzianum (4), but as with the other physiological tests, we do not know the importance of the individual metabolites, and it is not obvious what these differences mean for the biocontrol ability of the fungus.

One should not overestimate the results of the physiological studies of the transformants, because competitive ability and antagonism, which depend on multiple factors, cannot be evaluated in these kinds of tests. All the assays confirmed that transformant T3a best resembled the phenotype of the wild-type, whereas transformant T3c, although morphologically similar, appeared to be dissimilar in most of the tests. The results from the physiological tests indicate the importance of evaluating transformants before carrying out time-consuming ecological studies. For the ecological experiments (13), we chose transformant T3a. In addition to ecological studies and the possibility of expressing homologous and heterologous genes in T. harzianum, transformation is a powerful technique in attempts to study the importance of specific genes in relation to biocontrol as well as to improve the biocontrol effect by addition of useful genes to the fungus.

By transforming $T$. harzianum with the GUS gene as the reporter gene, we now have a tool for studying the population development of the antagonist in soil and rhizosphere, measuring its activity, as well as studying niche competition on the root surface. Results are reported in a subsequent paper (13). Visualization of isolate T3a in situ on cucumber roots and studies of its ability to compete with other antagonists also has been investigated (C. Thrane, A. Tronsmo, and D. F. Jensen, unpublished data).

\section{LITERATURE CITED}

1. Baker, K. F., and Cook, R. J. 1974. Biological control of plant pathogens. W. H. Freeman and Company, San Francisco.

2. Booth, C. 1971. The Genus Fusarium. Commonwealth Mycological Institute, Kew, Surrey, England.

3. Chet, I. 1987. Trichoderma-Application, mode of action, and potential as a biocontrol agent against plant pathogenic fungi. Pages $137-160$ in: Innovative Approaches to Plant Disease Control. I. Chet., ed. Wiley and Sons, New York.

4. Claydon, N., Hanson, A. M., Hanson, J. R., and Avent, A. G. 1987. Antifungal alkyl pyrones of Trichoderma harzianum. Trans. Br. Mycol. Soc. 88:503-513.

5. Couteaudier, Y., Daboussi, M. J., Eparvier, A., Langin, T., and Orcival, J. 1993. The GUS gene fusion system (Escherichia coli $\beta$-D-glucuronidase gene), a useful tool in studies of root colonization by Fusarium oxysporum. Appl. Environ. Microbiol. 59:1767-1773.
6. Elad, Y., Chet, I., and Henis, Y. 1981. A selective medium for improving quantitative isolation of Trichoderma spp. from soil. Phytoparasitica 9: 59-67.

7. Filtenborg, O., Frisvad, J. C., and Thrane, U. 1990. The significance of yeast extract composition on metabolite production in Penicillium. Pages 433-441 in: Modern Concepts in Penicillium and Aspergillus Classification. R. A. Samson and J. I. Pitt, eds. Plenum Press, New York.

8. Frisvad, J. C. 1994. Correspondence, principal coordinate, and redundancy analysis used on mixed chemotaxonomical qualitative and quantitative data. Chemometrics Intelligent Lab. Syst. 23:213-229.

9. Frisvad, J. C., and Thrane, U. 1987. Standardized high-performance liquid chromatography of 182 mycotoxins and other fungal metabolites based on alkylphenone retention indices and UV-VIS spectra (diode array detection). J. Chromatogr. 404:195-214.

10. Geremia, R. A., Goldman, G. H., Jacobs, D., Ardiles, W., Vila., S. B., van Montagu, M., and Herrera-Estrella, A. 1993. Molecular characterization of the proteinase-encoding gene, prbl, related to mycoparasitism by Trichoderma harzianum. Mol. Microbiol. 8:603-613.

11. Gerhardt, P., Murray, R. G. E., Constilow, R. N., Nester, E. W., Willis, W., Krieg, N. R., and Philips, G. B. 1981. Manual of Methods for General Methodology. American Society for Microbiology, Washington D.C.

12. Goldman, G. H., van Montagu, M., and Herrera-Estrella, A. 1990. Transformation of Trichoderma harzianum by high-voltage electric pulse. Curr. Genet. 17:169-174.

13. Green, H., and Jensen, D. F. 1995. A tool for monitoring Trichoderma harzianum: II. The use of GUS transformants for ecological studies in the rhizosphere. Phytopathology 85:1436-1440.

14. Herrera-Estrella, A., Goldman, G. H., and van Montagu, M. 1990. Highefficiency transformation system for the biocontrol agent Trichoderma harzianum. Mol. Microbiol. 4:839-843.

15. Hong, S.-W., and Park, H.-M. 1985. Protoplast fusion in the cellulolytic fungi, Trichoderma spp. Natl. Acad. Sci. Repub. Korea Nat. Sci. Ser. 24: 53-89.

16. Isaac, S. 1985. Metabolic properties of protoplasts. Mycol. Ser. 6:171-188.

17. Jefferson, R. A. 1987. Assaying chimeric genes in plants: The GUS gene fusion system. Plant Mol. Biol. Rep. 5:387-405.

18. Jensen, D. F., and Wolffhechel, H. 1995. The use of fungi, particularly Trichoderma spp. and Gliocladium spp., to control root rot and dampingoff diseases. Pages 177-189 in: Biocontrol Agents: Benefits and Risks. J. M. Lynch and H. Hokkanen, eds. Cambridge University Press, Cambridge.

19. Liljeroth, E., Jansson, H.-B., and Schäfer, W. 1993. Transformation of Bipolaris sorokiniana with the GUS gene and use for studying fungal colonization of barley roots. Phytopathology 83:1484-1489.

20. Lorito, M., Harman, G. E., Hayes, C. K., Broadway, R. M., Tronsmo, A., Woo, S. L., and Di Pietro, A. 1993. Chitonolytic enzymes produced by Trichoderma harzianum: Antifungal activity of purified endochitinase and chitobiosidase. Phytopathology 83:302-307.

21. Lorito, M., Hayes, C. K., Di Pietro, A., and Harman, G. E. 1993. Biolistic transformation of Trichoderma harzianum and Gliocladium virens using plasmid and genomic DNA. Curr. Genet. 4:349-356.

22. Lynch, J. 1989. Environmental potential of the Trichoderma exocellular enzyme system. Pages 608-618 in: Plant Cell Wall Polymers. Biogenesis and Biodegradation. N. G. Lewis and M. G. Paice, eds. American Chemical Society, Washington D.C.

23. Messner, R., and Kubicek, C. P. 1990. Synthesis of cell wall glucan, chitin and protein by regenerating protoplasts and mycelia of Trichoderma reesei. Can. J. Microbiol. 36:211-217.

24. Nation, J. L. 1983. A new method using hexamethyldisilzane for preparation of soft insect tissue for scanning electron microscopy. Stain Technol. $58: 347-351$

25. Necâs, O., and Svoboda, A. 1985. Cell wall regeneration and protoplast reversion. Mycol. Ser. 6:115-134.

26. Nevalainen, K. M. H., Penttilä, M. E., Harkki, A., Teeri, T. T., and Knowles, J. 1991. The molecular biology of Trichoderma and its application to the expression of both homologous and heterologous genes. Pages 129-148 in: Molecular Industrial Mycology. S. A. Leong and R. M. Berkka, eds. Marcel Dekker, Inc., New York.

27. Newbury, D. E., Joy, D. C., Echlia, P., Fiori, C. E., and Goldstein, J. I. 1986. Advances in scanning electron microscopy and $\mathrm{x}$-ray analysis. Plenum Press, New York.

28. Ogawa, K., Ohara, H., and Toyama, N. 1988. Interspecific hybridization of Aspergillus awamori var. kawachi and Aspergillus oryzae by protoplast fusion. Agric. Biol. Chem. 52:1985-1991.

29. Oliver, R. P., Farman, M. L., Jones, J. D. G., and Hammond-Kosack, K. E. 1993. Use of fungal transformants expressing $\beta$-glucuronidase activity to detect infection and measure hyphal biomass in infected plant tissues. Mol. Plant-Microbe Interact. 6:521-525.

30. Pe'er, S., Barak, Z., Yarden, O., and Chet, I. 1991. Stability of Tricho- 
derma harzianum amdS transformants in soil and rhizosphere. Soil Biol. Biochem. 23:1043-1046.

31. Penttilä, M. E., André, L., Saloheimo, M., Lehtovaara, P., and Knowles, J. K. C. 1987. Expression of two Trichoderma reesei endoglucanases in the yeast Saccharomyces cerevisiae. Yeast 3:175-185.

32. Penttilä, M. E., Nevalainen, H., Rättö, M., Salminen, E., and Knowles, J. 1987. A versatile transformation system for the cellulolytic filamentous fungus Trichoderma reesei. Gene 61:155-164.

33. Raeder, U., and Broda, P. 1985. Rapid preparation of DNA from filamentous fungi. Lett. Appl. Microbiol. 1:17-20.

34. Roberts, I. N., Oliver, R. P., Punt, P. J., and van den Hondel, C. A. M. J. J. 1989. Expression of Escherichia coli $\beta$-glucuronidase gene in industrial and phytopathogenic filamentous fungi. Curr. Genet. 15:177-180.

35. Rohlf, F. J. 1993. NTSYS-pc: Numerical Taxonomy and Multivariate Analysis System. Version 1.80. Exeter Software, Setauket, NY.

36. Sambrook, J., Fritsch, E. F., and Maniatis, T. 1987. Molecular Cloning: A Laboratory Manual. 2nd ed. Cold Spring Harbor Press, Cold Spring Harbor, NY

37. Scott, P. M., Lawrence, J. W., and van Walbeck, W. 1970. Detection of mycotoxins by thin-layer chromatography: Application to screening of fungal extracts. Appl. Microbiol. 20:839-842.

38. Sivan, A., Harman, G. E., and Stasz, T. E. 1990. Transfer of isolated nuclei into protoplasts of Trichoderma harzianum. Appl. Environ. Microbiol. 56:2404-2409.

39. Sivan, A., Stasz, T. E., Hemmat, M., Hayes, C. K., and Harman, G. E. 1992.
Transformation of Trichoderma spp. with plasmids conferring hygromycin B resistance. Mycologia 84:687-694.

40. Smith, G. 1949. The effects of adding trace metals to Czapek-Dox culture medium. Trans. Br. Mycol. Soc. 32:280-283.

41. Thrane, U. 1986. Detection of toxigenic Fusarium isolates by thin layer chromatography. Lett. Appl. Microbiol. 3:93-96.

42. Thrane, U. 1990. Grouping Fusarium section Discolor isolates by statistical analysis of quantitative high performance liquid chromatographic data on secondary metabolite production. J. Microbiol. Methods 12:23-39.

43. Toyama, H., Yokoyama, T., Shinmyo, A., and Okada, H. 1984. Interspecific protoplast fusion of Trichoderma. J. Biotechnol. 1:25-35.

44. Tronsmo, A., and Harman, G. E. 1992. Coproduction of chitonolytic enzymes for biological control by Trichoderma harzianum on media containing chitin. Biol. Control 2:272-277.

45. Tronsmo, A., and Harman, G. E. 1993. Detection and quantification of $\mathrm{N}$-acetyl- $\beta$-D-glucosaminidase, chitobiosidase, and endochitinase in solutions and on gels. Anal. Biochem. 208:74-79.

46. van Gorcom, R. F. M., Pouwells, P. H., Goosen, T., Visser, J., van den Broek, H. W. J., Hamer, J. E., Timberlake, W. E., and van den Hondel, C. A. M. J. J. 1985. Expression of an Escherichia coli $\beta$-galactosidase fusion gene in Aspergillus nidulans. Gene 40:99-106.

47. Wolffhechel, H. 1989. Fungal antagonists of Pythium ultimum isolated from a disease suppressive sphagnum peat. Växtskyddsnotiser 53:7-11.

48. Zimmerman, U., and Vienken, J. 1982. Electric-field-induced cell-to-cell fusion. Membr. Biol. 67:165-182. 